\title{
The association between Institutional Absorptive Capacity, Electronic Procurement Assimilation and Procurement Process in Public Sector Organizations
}

\author{
John Manso Frimpong \\ Kwame Nkrumah University of \\ Science \& Technology \\ jfrimpongmanso.ksb@knust.edu \\ . $\mathrm{gh}$
}

\author{
Francis Kofi Andoh-Baidoo \\ University of Texas Rio Grande \\ Valley \\ francis.andohbaidoo@utrgv.edu
}

\author{
David Asamoah \\ Kwame Nkrumah University of \\ Science \& Technology \\ dasamoah.ksb@knust.edu.gh
}

\begin{abstract}
Public sector organizations face challenges with their procurement processes. Electronic mode of public procurement enables governments and organizations to achieve efficient and effective tendering information processing, leading to transparency and fairness in the bidding process. However, little is known on the drivers of electronic procurement assimilation in the public sector. The study examines the influence of absorptive capacity on the assimilation of electronic procurement and subsequent effect on the procurement process in the public sector. In addition, the study explores the mediating role of electronic procurement assimilation on the relationship between institutional absorptive capacity and the procurement process. Structural equation modelling was used to analyze 306 useable data from public sector organizations in Ghana where public procurement laws demand efficient and effective procurement processes. We found support for all the four hypotheses. We offer theoretical and managerial implications.
\end{abstract}

Keywords: Electronic procurement, assimilation, absorptive capacity, public sector

\section{Introduction}

The assimilation of information systems (IS) innovations has been extensively studied [10, 31, 7, 33, 28]. Electronic procurement (e-procurement), one such innovation, is breaking new grounds in the public sector in the advanced and emerging economies [41]. Electronic procurement is the use of Internet-based information and communication technologies to carry out some or all stages of the procurement process including search, sourcing, negotiation, ordering, receipt, and post-purchase review [9]. Electronic procurement is not about replacing the manual transactional activities with the electronic means but re-engineering of the process. The assimilation of IS innovations requires prior knowledge and competence in building individual and institutional capacity to sustain such innovations [14]. Thus, studies on the influence of absorptive capacity is predominant in IS assimilation literature [34, 41]. Aggressive technology policy forces organizations to expand and enhance their knowledge base to process a new technology assimilation [34]. Volberda et al. [39] argue that firms with higher absorptive capacity assimilate better than their counterparts. Few studies have examined the relationships between absorptive capacity and e-procurement [32, 29]. However, these studies were conducted in the private sector. Some scholars call for extension of e-procurement studies in the public sector [34]. E-procurement assimilation has potential to address deviant behaviors such as corruption which is depriving governments of the scarce resources. Previous studies on e-procurement assimilation have emphasized on IT infrastructure and not on management and actors' competence and capabilities and other soft capacities such as prior knowledge.

There is anecdotal evidence that lack of absorptive capacity will prevent public institutions from effective assimilation of e-procurement. The current study seeks to address this gap in IS and public procurement literature. Experience accumulation and knowledge articulation are essential in developing capability with an organization [17]. Therefore, prior knowledge and 
experience of managers, buyers and other key actors in public procurement could advance an efficient and effective procurement process. The reason is that the procurement process typically involves a large amount of information processing and communication and organizations need to build information processing capacity to meet the requirements of the procurement information processing [13]. Therefore, this study examines the relationship between institutional absorptive capacity, e-procurement assimilation and public procurement process. Data was collected from Ghana where recent procurement laws demands efficient and effective procurement processes. The findings of the study support the proposed hypotheses. The study offers theoretical, managerial and policy implications.

The rest of the study is presented as follows. The theoretical review and hypothesis development section is presented next, followed by the methodology. This leads to the results and discussions section, followed by the conclusion section which elaborates on the implications of the study, limitations of the study and directions for future research.

\section{Theoretical review and hypothesis development}

\subsection{Absorptive capacity}

Absorptive capacity is defined as the ability to recognize the value of new information, assimilate it and apply it to commercial ends [7]. Three dimensions of absorptive capacity have been identified namely; recognizing the value of external knowledge, assimilating and applying it [45].

Some researchers recognized that the study of absorptive capacity has undergone an inappropriate deviation from the original purpose and identified some critical assumptions to explain the developments since 1990 [23, 35]. Other scholars argue that absorptive capacity enables organizations to predict the nature of technological advances and acknowledged the efficiency view [45].

Since 1990, absorptive capacity has been modelled by various authors on components, antecedents, contingent factors and outcomes [1, 13]. All the models agreed that inter-organizational factors and prior knowledge are the main antecedents of absorptive capacity.

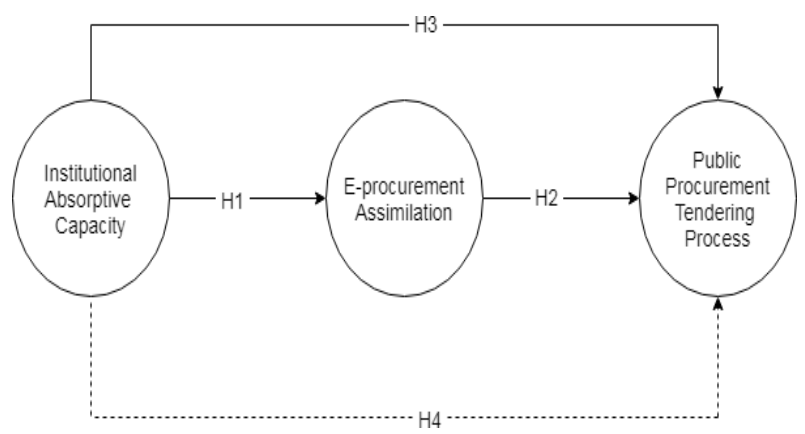

Figure 1: Theoretical model

\subsection{Absorptive capacity and e-procurement assimilation}

Organizations dedicate more of their resources (e.g. expenditure services, software, infrastructure and human resource enhancement) towards developing and building absorptive capacity to take advantage of innovation for marketplace competition [1]. Therefore, absorptive capacity has become important in IS innovation and assimilation. This is evidenced from absorptive capacity literature which acknowledge innovation as one of its main outcomes $[7,35,34,40]$. A study suggests that the absorptive capacity of an organization has positive effect on innovation [24]. Absorptive capacity enables an organization to obtain information, allows it to make external information useful and develop new capabilities [21]. It is posited that an aggressive technology policy allows organizations to expand and enhance their knowledge base to process new technology assimilation [34]. A study investigated the antecedents of RFID assimilation and hypothesized that a company with highly integrated IT infrastructure assimilate better than its competitors [42]. Another study found a direct effect of absorptive capacity on social media assimilation, arguing that previous experience with similar technology and the general ability to learning and apply a new technology foster assimilation [5].

The level of IT sophistication and e-procurement innovation infrastructure have been found to influence e-procurement innovation assimilation in previous studies [32, 30]. Based on the prior discussion, we hypothesize that:

H1: An institution's absorptive capacity has positive influence on its e-procurement assimilation in the public sector. 


\subsection{Absorptive capacity and the procurement process}

Experience accumulation and knowledge articulation are essential in developing capability with an organization [18]. It is stated that Federal agencies in the USA should hire contractors who have adequate knowledge, competence and experience in contract management [4]. By extension, the actors in the procurement process ought to have the same or better levels of knowledge, competence and experience to execute the procurement agenda in their respective organizations.

The contracting authority could achieve the acquisition goals and performance. The tasks needed to be performed in the procurement process are sometimes regarded as tendering competency [27]. This is so because practitioners of public procurement need to build task competence to perform the tendering process satisfactorily. This capacity is enhanced through establishing proper communication channels and requires the formation of cross-functional teams, information, experience and ideas sharing to better position the procurement process for success. The development of the necessary absorptive capacity by the actors in the public procurement function has therefore become inevitably significant to comply with procurement procedures. These competencies, experiences and knowledge sharing form the institution's absorptive capacity so far as procurement is concerned. The more these competencies are developed by actors in public procurement, the better the performance of the tendering process. On these bases, this study proposes that:

H2: An institution's absorptive capacity has a positive influence on public procurement (tendering) process.

\subsection{E- Procurement assimilation and procurement process}

IT assimilation is regarded as an important outcome in the effort of organizations to leverage the potential of IT in their business activities and strategies [3]. But few studies have examined the effect of e-procurement as an independent variable on procurement productivity $[31,32]$.

E-procurement initiatives in the public sector should modernize public procurement and improve public procurement goals [30], and by extension, value for money.

While [39] posits that e-procurement improves the efficiency and effectiveness of procurement through increase in usage patterns, others have established positive relationship between eprocurement and performance $[9,8,22]$.

The procurement process typically involves a large amount of information processing and communication [13]. At the pre-tendering and tendering stages, information exchange between the contracting organization and the tenderers must be enough to encourage participation, competition and decision making. An equal measure of information exchange is expected at the post-tendering stage between the contracting organization and the supplier or contractor to aid execution and performance. Therefore, in the context of public procurement system, organizations need to build information processing capacity to meet the requirements of the procurement information processing. Any difference between the two creates a gap, as conceptualized by Information Processing Theory $[33,17]$.

Emerging technologies (such as e-procurement tools) are reversing the tradition of costly, time-consuming and inefficient procurement processes [10]. Therefore, the extent of IT infusion in public procurement process will have significant impact on the procurement process requirements, which eventually makes the procurement process efficient. The use of e-procurement applications is focused on making the traditional purchasing function more efficient and cost effective [42]. Similarly, it is in the light of the above regarding e-procurement assimilation in public sector procurement, we hypothesize that:

H3: E-procurement assimilation in public sector procurement has a significant effect on public procurement process efficiency.

\subsection{Mediating effect of e-procurement assimilation}

We have hypothesized in this study that institutional absorptive capacity significantly influences both eprocurement assimilation and the procurement process in the public sector. We have also indicated that e-procurement assimilation on the other hand, has a direct significant effect on the public procurement process. Thus, e-procurement assimilation plays a mediation role in the relationship between institutional absorptive capacity and public 
procurement process. This is so because, a company with high absorptive capacity can go further along in the assimilation process than others, and is well placed to assimilate complex IT applications, which enables organizations to process procurement information more efficiently and effectively. Thus, we explore this indirect effect of e-procurement assimilation by hypothesizing that:

H4: E-procurement assimilation mediates the relationship between institutional absorptive capacity and public procurement process.

\section{Methodology}

Established measures for absorptive capacity, eprocurement assimilation and procurement process were adapted from existing literature with little modification. The measure of absorptive capacity is adapted from [36]. The absorptive capacity construct comprises of five sub-constructs-manager's competence, buyer's competence, communication climate, communication network, and knowledge scanning [22]. We argue that in the practice of public procurement, users play a crucial role because it is their demand and request that trigger the process and their knowledge is a capacity that cannot be ignored. Therefore, user's prior knowledge is added as the sixth sub-construct of absorptive capacity [26, 44]. The current study modifies the scale from the traditional Likert scale to a matrix, where respondents were asked to match the stages of assimilation (i.e. awareness, interest, evaluation/trial, commitment, limited deployment and general deployment) with the steps in the tendering process. Ten (10) steps of the tendering process are identified and grouped into 3 phases - pre-tendering, tendering and post-tendering phases [29]. The measurement items of assimilation are deemed to be formative as the dimensions are viewed as defining the characteristics of assimilation and any change in the dimensions would lead to a change in the focal construct (e-procurement assimilation) [25].

A 5-point Likert scale was used to measure procurement (tendering) process. The rationale is to assess whether public sector organizations follow the best practices in public procurement tendering. This study adopted the procurement process of OECD, made up of ten (10) sequential activities [29]. The procurement process is categorized into pretendering, tendering and post-tendering phases. Six (6) items are used to measure pre-tendering and tendering phases, while five (5) for post-tendering phase.

The study setting is Ghana and the population is composed of Entity Tender Committee and Tender Review Boards of the respective public organizations and ministries. The sampling frame consists of all public organizations which by law are expected to use Ghana's Public Procurement Act 663 for their procurement activities. This study uses multistage cluster sampling technique to sample 370 public sector organizations with 306 usable responses. The determination of the sample size follows the procedure recommended by [19] for variance-based Structural Equation Modelling (SEM). With respect to respondent population, the study targets heads of entity, directors and deputy directors, procurement directors and deputies, engineers, architects, accountants and finance officers, heads of stores, heads of user departments and heads of operations. The selection of these individuals is based on three key factors - (1) they are senior managers of the entities and they represent the face of the organizations, (2) they have adequate knowledge in the procurement process and (3) most of them are members of the Entity Tender Committee and Tender Review Boards of the respective organizations and ministries. As a result, convenience sampling is used to select a respondent from each entity. Structural Equation Modelling is used to assess the hypothesized causal paths among the constructs. SEM is a family of statistical procedures that analyses multiple relationships among latent constructs using equations quite similar to multiple regression equations [16]. Because this study is theory building and exploratory in nature, a variance-based SEM is considered more suitable, for which Smart PLS is used for the analysis.

\section{Results and Discussion}

\subsection{Characteristics of Respondents}

Table 1 shows the profile of the respondents. In terms of educational background, $98 \%$ had first degree or above, the respondents who have more than 5 years' experience in public service, procurement and/or related industry accounts for $76 \%$ and in terms of industry description, $12.4 \%$ education, $11.1 \%$ health, $7.8 \%$ agriculture, $5.6 \%$ road and transport, 5.6\% works and housing, $13.1 \%$ science, technology and research, $15.3 \%$ state-owned enterprises, $6.2 \%$ utilities and $22.9 \%$ others. All the respondents are members of the Entity Tender 
Committee or Tender Review Boards of their respective organizations and/or ministries.

Table 1. Respondents' Characteristics

\begin{tabular}{|c|c|c|c|}
\hline \multicolumn{2}{|c|}{ Demographic } & \multirow{2}{*}{$\begin{array}{r}\text { Number } \\
6\end{array}$} & \multirow{2}{*}{$\begin{array}{r}\text { Percent } \\
1.96\end{array}$} \\
\hline Education & Secondary & & \\
\hline & First degree & 116 & 37.91 \\
\hline & Second degree & 122 & 39.87 \\
\hline & Professional & 62 & 20.26 \\
\hline & Total & 306 & 100 \\
\hline \multirow[t]{6}{*}{ Experience } & $<6$ & 74 & 24.18 \\
\hline & $6-10$ & 109 & 35.62 \\
\hline & $11-15$ & 63 & 20.59 \\
\hline & $16-20$ & 35 & 11.44 \\
\hline & $>20$ & 25 & 8.17 \\
\hline & Total & 306 & 100 \\
\hline \multirow{10}{*}{$\begin{array}{l}\text { Industry } \\
\text { types }\end{array}$} & Education & 38 & 12.4 \\
\hline & Health & 34 & 11.1 \\
\hline & Agriculture & 24 & 7.8 \\
\hline & $\begin{array}{l}\text { Road and } \\
\text { Transport }\end{array}$ & 17 & 5.6 \\
\hline & $\begin{array}{l}\text { Works and } \\
\text { Housing }\end{array}$ & 17 & 5.6 \\
\hline & $\begin{array}{l}\text { Science and } \\
\text { Technology }\end{array}$ & 40 & 13.1 \\
\hline & $\begin{array}{l}\text { State- own } \\
\text { Enterprise }\end{array}$ & 47 & 15.3 \\
\hline & Utility & 19 & 6.2 \\
\hline & Others & 70 & 22.9 \\
\hline & Total & 306 & 100 \\
\hline
\end{tabular}

\subsection{Measurement model result}

The measurement model was assessed to ensure they were sound. This was done by assessing the convergent validity and discriminant validity.

\section{Tests of Convergent}

\section{Validity}

Convergent validity refers to the relationship between measures of a common construct and reflects the extent to which two measures capture the same information [5]. The more similar the information they capture, the more likely they are to produce equivalent results. Convergent validity was assessed by ensuring there is adequate composite reliability and average variance extracted (AVE). All were found to be above the irrespective recommended thresholds (AVE $>0.5$, Composite reliability, Cronbach's alpha and rho_A $>0.7)$ as indicated in Table 2. Further, an examination of the factor loadings revealed that all items loaded highly on their constructs (above 0.7).

\section{Table 2: Tests of Convergent Validity}

\begin{tabular}{|l|c|c|c|c|}
\hline & $\begin{array}{c}\text { Cronbach's } \\
\text { Alpha }\end{array}$ & rho_A & $\begin{array}{c}\text { Composite } \\
\text { Reliability }\end{array}$ & AVE \\
\hline BK & 0.825 & 0.832 & 0.884 & 0.658 \\
\hline CC & 0.909 & 0.910 & 0.927 & 0.646 \\
\hline CN & 0.842 & 0.845 & 0.894 & 0.679 \\
\hline KS & 0.887 & 0.889 & 0.912 & 0.597 \\
\hline MK & 0.807 & 0.808 & 0.874 & 0.634 \\
\hline POTP & 0.768 & 0.768 & 0.866 & 0.683 \\
\hline PTP & 0.707 & 0.710 & 0.872 & 0.773 \\
\hline TP & 0.832 & 0.838 & 0.889 & 0.667 \\
\hline UK & 0.819 & 0.823 & 0.881 & 0.649 \\
\hline
\end{tabular}

$\mathrm{BK}=$ Buyer Knowledge, $\mathrm{CC}=$ Communications Climate, $\mathrm{CN}=$ Communications Network, $\mathrm{KS}=$ Knowledge Scanning, $\mathrm{MK}=$

Management Knowledge, POTP = Post-Tendering Processes, $\mathrm{PTP}=$ Pre-Tendering Processes, TP $=$ Tendering Processes, UK $=$ User Knowledge.

\section{Tests of Discriminant Validity}

Next, the model was tested for adequate discriminant validity. Discriminant validity assessment has become a prerequisite for analyzing relationships among variables in SEM [15]. Heterotrait-monotrait ratio of correlations (HTMT) is tested. Table 3 indicates that the highest HTMT value is 0.807 , meeting the requirement of HTMT $<0.9$ or stringent requirement of $<0.85$ confirming the model possesses adequate discriminant validity. 
Table 3 HTMT results

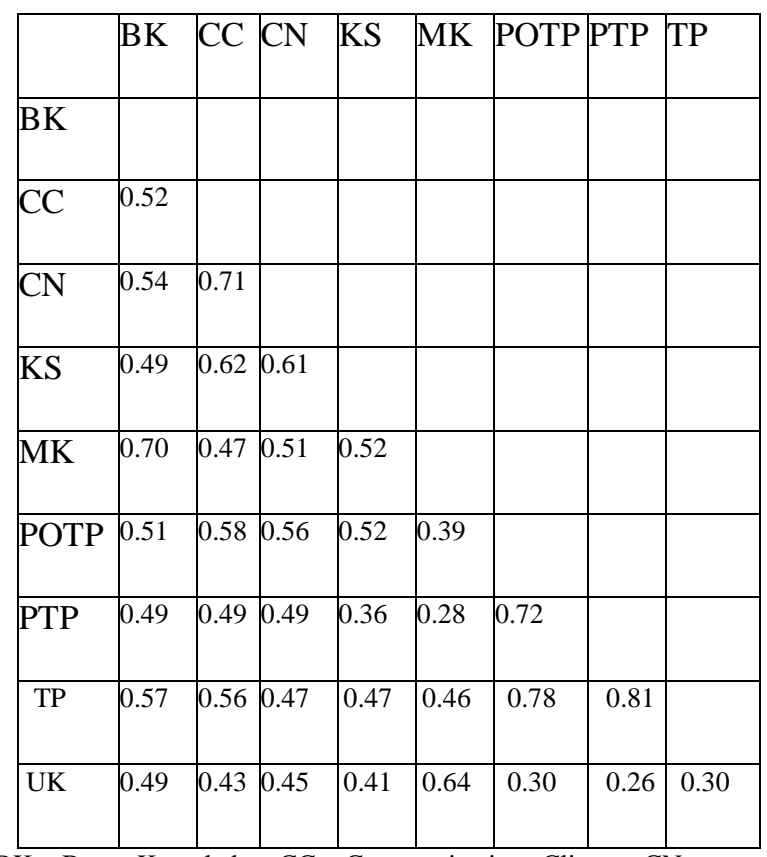

$\mathrm{BK}=$ Buyer Knowledge, $\mathrm{CC}=$ Communications Climate, $\mathrm{CN}=$ Communications Network, $\mathrm{KS}=$ Knowledge Scanning, $\mathrm{MK}=$

Management Knowledge, POTP $=$ Post-Tendering Processes, PTP = Pre-Tendering Processes, TP $=$ Tendering Processes, UK $=$ User Knowledge.

To further assess discriminant validity, Fornell-Larcker criterion analysis was performed to show the extent to which the latent constructs explain better the variance of their own indicators than the variance of other constructs [10]. The result shows that all diagonal variables are greater than off-diagonal values, confirming discriminant validity of the model as in Table 4.
Table 4 Fornell Larcker criterion

\begin{tabular}{|l|r|r|r|r|r|r|l|l|l|}
\hline & BK & CC & CN & KS & MK & $\begin{array}{l}\text { PO } \\
\text { TP }\end{array}$ & $\begin{array}{l}\text { PT } \\
\text { P }\end{array}$ & TP & UK \\
\hline BK & $\mathbf{0 . 8}$ & & & & & & & & \\
& $\mathbf{1 1}$ & & & & & & & & \\
\hline CC & 0.4 & $\mathbf{0 . 8}$ & & & & & & & \\
& 50 & $\mathbf{0 4}$ & & & & & & & \\
\hline CN & 0.4 & 0.6 & $\mathbf{0 . 8}$ & & & & & & \\
& 53 & 25 & $\mathbf{2 4}$ & & & & & & \\
\hline KS & 0.4 & 0.5 & 0.5 & $\mathbf{0 . 7}$ & & & & & \\
& 16 & 58 & 31 & $\mathbf{7 2}$ & & & & & \\
\hline M & 0.5 & 0.4 & 0.4 & 0.4 & $\mathbf{0 . 7}$ & & & & \\
K & 73 & 01 & 20 & 38 & $\mathbf{9 6}$ & & & & \\
\hline PO & 0.4 & 0.4 & 0.4 & 0.4 & 0.3 & $\mathbf{0 . 8}$ & & & \\
TP & 08 & 85 & 51 & 32 & 04 & $\mathbf{2 6}$ & & & \\
\hline PT & 0.3 & 0.3 & 0.3 & 0.2 & 0.2 & 0.5 & $\mathbf{0 . 8}$ & & \\
P & 67 & 95 & 78 & 86 & 07 & 30 & $\mathbf{7 9}$ & & \\
\hline TP & 0.4 & 0.4 & 0.3 & 0.4 & 0.3 & 0.6 & 0.6 & $\mathbf{0 . 8}$ & \\
& 75 & 80 & 92 & 06 & 76 & 21 & 20 & $\mathbf{1 7}$ & \\
\hline UK & 0.4 & 0.3 & 0.3 & 0.3 & 0.5 & 0.2 & 0.1 & 0.2 & $\mathbf{0 . 8}$ \\
& 05 & 67 & 73 & 44 & 20 & 37 & 97 & 43 & $\mathbf{0 6}$ \\
\hline
\end{tabular}

$\mathrm{BK}=$ Buyer Knowledge, $\mathrm{CC}=$ Communications Climate, $\mathrm{CN}=$ Communications Network, KS = Knowledge Scanning, $\mathrm{MK}=$ Management Knowledge, POTP = Post-Tendering Processes, PTP = Pre-Tendering Processes, TP $=$ Tendering Processes, UK $=$ User Knowledge.

\section{Test for Multicollinearity}

The Variance Inflation Factor VIF was generated for the formative indicators of "Assimilation" construct using Smart PLS software. From Table 5, it is observed that all VIF values are uniformly below the recommended threshold value of 5 [15].

Table 5 VIF results

\begin{tabular}{|c|c|}
\hline \multicolumn{2}{|c|}{ ASSIMILATION } \\
\hline Indicators & VIF \\
\hline ASS1 & 2.34 \\
\hline ASS2 & 1.91 \\
\hline ASS3 & 2.83 \\
\hline ASS4 & 2.96 \\
\hline ASS5 & 2.83 \\
\hline ASS6 & 2.58 \\
\hline ASS7 & 2.13 \\
\hline ASS8 & 3.10 \\
\hline ASS9 & 2.89 \\
\hline
\end{tabular}




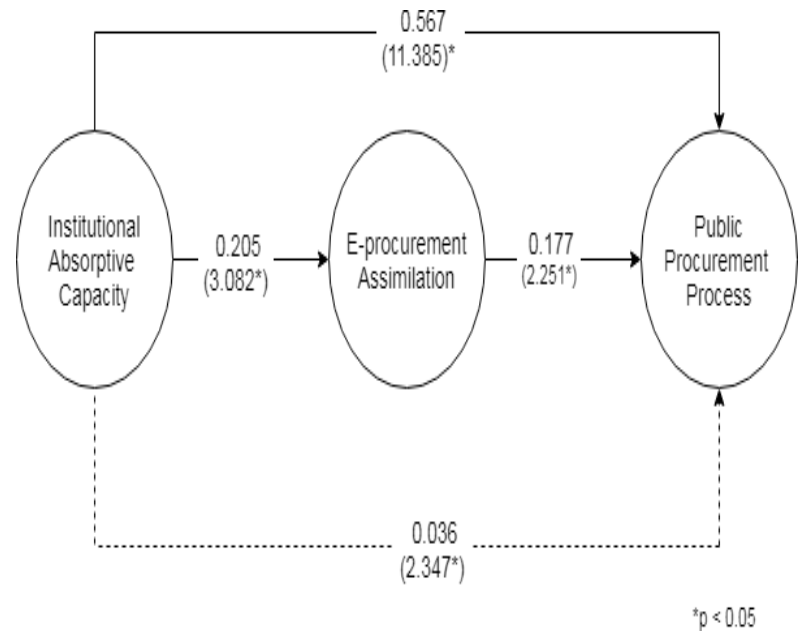

Figure 2 Structural model

The structural model revealed that the $\mathrm{R}^{2}$ of the Procurement Process (TENDP) is $39.4 \%$, which represents a moderate level of variance explained for this construct. The $\mathrm{R}^{2}$ of E-procurement Assimilation on the other hand was $4.2 \%$, which represents a weak level of variance explained.

\section{Table 6 Summary of results}

\begin{tabular}{|c|l|l|l|l|}
\hline $\mathbf{H}$ & Hypothesis & $\boldsymbol{\beta}$ & $\begin{array}{l}\text { t- } \\
\text { value }\end{array}$ & $\begin{array}{l}\text { Hypothesis } \\
\text { support }\end{array}$ \\
\hline $\mathrm{H}_{1}$ & $\begin{array}{l}\text { IAS } \rightarrow \\
\text { ASSIM }\end{array}$ & 0.205 & 3.082 & $\begin{array}{l}\text { Supported } \\
\text { at } p<0.05\end{array}$ \\
\hline $\mathrm{H}_{2}$ & $\begin{array}{l}\text { ASSIM } \rightarrow \\
\text { TENDP }\end{array}$ & 0.177 & 2.251 & $\begin{array}{l}\text { Supported } \\
\text { at } p<0.05\end{array}$ \\
\hline $\mathrm{H}_{3}$ & $\begin{array}{l}\text { IAS } \rightarrow \\
\text { TENDP }\end{array}$ & 0.567 & 11.385 & $\begin{array}{l}\text { Supported } \\
\text { at } p<0.05\end{array}$ \\
\hline $\mathrm{H}_{4}$ & $\begin{array}{l}\text { IAS } \rightarrow \\
\text { ASSIM } \rightarrow \\
\text { TENDP }\end{array}$ & 0.036 & 2.347 & $\begin{array}{l}\text { Supported } \\
\text { at } p<0.05\end{array}$ \\
\hline
\end{tabular}

From Figure 2 and Table 6, all the hypothesized paths were supported. The influence of eprocurement assimilation on public procurement processes was positive and significant $(\beta=0.177 ; \mathrm{t}=$ $2.251 ; p<0.05)$. This suggests that the level of eprocurement assimilation influences the effectiveness of public procurement processes in the surveyed organizations. The public sector procurement process consists of a series of related (and sometimes unrelated) activities which is taskintensive in the sense that it involves many tasks and requires human effort to accomplish. The results confirmed that high levels of e-procurement enabled the firms to become more effective and efficient in their procurement processes. Therefore, the introduction and application of e-procurement must be seen as an effort to modernize the procurement process to improve the efficiency and effectiveness [31]. As [13] put it, e-procurement as an emerging technology in developing economies is reversing the time-consuming and inefficient procurement process. This is evidenced in this current study where about $39.4 \%$ of the success of the procurement process is explained by the combined effects of institutional absorptive capacity and eprocurement assimilation in the public sector.

The results of the analysis further revealed that institutional absorptive capacity had a positive and significant effect on institutions' public procurement processes $(\beta=0.567 ; \mathrm{t}=11.385 ; \mathrm{p}<$ $0.05)$. This indicates that an institution's absorptive capacity significantly shapes the effectiveness and efficiency of its public procurement activities. A certain level of absorptive capacity has to be attained to improve end-to-end processes [30]. Public procurement processes are implemented by different people from different backgrounds who require adequate level of absorptive capacity [2].

The findings also indicated that institutional absorptive capacity had a positive and significant effect on e-procurement assimilation $(\beta=$ $0.205 ; \mathrm{t}=3.082 ; \mathrm{p}<0.05)$. Organizations build absorptive capacity and use acquired knowledge to take advantage of innovation [1]. Absorptive capacity enables an organization to obtain useful information and develop new capabilities for innovation [21]. Through absorptive capacity, organizations build IT infrastructure useful for eprocurement assimilation. This suggests that the extent of e-procurement application usage in an organization is dependent on the level of absorptive capacity. The higher the absorptive capacity of an organization, the deeper the extent of assimilation.

In addition, the current study hypothesizes indirect effect of institutional absorptive capacity on public procurement process mediated by eprocurement assimilation. The results affirm the proposition that e-procurement assimilation mediates the relationship between institutional absorptive capacity and public procurement processes $(\beta=0.036 ; \mathrm{t}=2.347 ; \mathrm{p}<0.05)$, but the size of the indirect effect is way smaller than the direct effect of institutional absorptive capacity on public procurement processes. This indicates that though e-procurement application enhances procurement information processing, without it 
public sector organizations can still utilize their absorptive capacity to achieve an efficient and effective procurement process. The relatively smaller effect of the mediation could also be attributed to the fact that public organizations have built more capacity for executing the procurement process with little emphasis on IT capacity to implement and assimilate e-procurement.

\section{Conclusion}

Absorptive capacity has long been identified as an antecedent of e-procurement adoption and assimilation in the advanced economies with little or no emphasis on developing economies and the public sector. The current study has confirmed that irrespective of the economic and industrial background, absorptive capacity will continue to drive the adoption and assimilation of eprocurement. Though assimilation of electronic applications in the procurement process helps to process information quicker to improve turnaround time to increase efficiency of the procurement system, the appropriate utilization of institutional absorptive capacity can achieve the same or better results. That is the extent of e-procurement application usage in an organization is dependent on the level of absorptive capacity. The higher the absorptive capacity of an organization, the deeper the extent of assimilation.

Practically, public entities, as a matter of necessity should build the absorptive capacity of their procurement actors, in such areas as competence in the use of electronic tools and of the procurement practice and information sharing through effective communication networks. These are necessary tools needed to scan, identify and assimilate new information necessary for eprocurement use and efficient procurement process. The significance of the electronic mode in this context is to facilitate and fast track the procurement information processing, reducing human errors, inculcating transparency and fairness in the bidding process. This will go a long way to enhance the confidence of tenderers in public procurement and also enable them to effectively respond to forces in the global sourcing marketplace.

\section{References}

[1] Addorisio, M., S. Gao, W. Yeoh, and S. F. Wong, "Critical analysis of the use of absorptive capacity theory in IS research", Proceedings of the 5th International Conference on Information Systems (ICIS 2014), Association for Information Systems (AIS), Auckland,
New Zealand, 2014, pp.1-15.

[2] Anton, M., A. Kovacic, M. I. Štemberger, and P. Trkman, "Absorptive Capacity as a Precondition for Business Process Improvement", Journal of Computer Information System, 2014, PP 35-43.

[3] Armstrong, C., and V. Sambamurthy, "Information technology assimilation of organizations: the influence of senior leadership and IT infrastructure", Information Systems Research, Vol. 18(2), 1999, 304-328.

[4] Baldwin, R., and S. Evenet, "The collapse of global trade, murky protectionism, and the crisis", VoxEU.org Publication, Centre for Economic Policy Research. EU, 2009.

Bharati, P, Zhang, C, and Chaudhury, A. "Social media assimilation in firms: Investigating the roles of absorptive capacity and institutional pressures". Information Systems Frontiers 16, no. 2 (2014): 257-272.

[5] Carlson, K.D., and A.O. Herdmans 2012. Understanding the impact of convergent validity on research results. Organizational Research Methods, 15(1), pp.17-32.

[6] Cohen, W. M., and D. A. Levinthal, Absorptive capacity: A new perspective on learning and innovation. Administrative Science Quarterly, 35(1), 1990, pp. 128152.

[7] Cooper V.A., Molla A. "Absorptive capacity and contextual factors that influence green IT assimilation". Australasian Journal of Information Systems. 2014 Nov $1: 18(3)$.

[8] Croom, S., and A. Brandon-Jones, "E-Procurement: Key issues in e-Procurement implementation and operation in the public sector", 13th International Purchasing \& Supply Education \& Research Association (IPSERA) Conference, April 4-7, Catania, Italy, 2014.

[9] De Boer L., J. Harink and G. Heijboer, "A conceptual model for assessing the impact of electronic procurement", European Journal of Purchasing and Supply Management, Vol. 8(1), 2002, pp.25-33

[10]Hamid M.R., Sami W., Sidek M.M. Discriminant validity assessment: Use of Fornell \& Larcker criterion versus HTMT criterion. Int. Journal of Physics: Conference Series 2017 Sep (Vol. 890, No. 1, p. 012163).

[11] Fichman, R.G., and C.F. Kemerer, "The assimilation of software process innovations: An organizational learning perspective", Management science, 43(10), 1997 , pp.1345-1363.

[12] Gao S, Yeoh W, Wong SF, Scheepers R. "A literature analysis of the use of absorptive capacity construct in IS research", International Journal of Information Management. 37(2), 2017, 36-42.

[13] Gebauer, J., C. Beam, and A. Segev, "Impact of the Internet on Procurement", Acquisition Review Quarterly, 5(2), 1998, pp.167-184. 
[14] Guides, H. P, Ziviani, F., Paiva, R. V. C., Ferreira, M. A. T. and Herzog, M. M. "Assessment of absorptive capacity: a study in Brazilian manufactures of solar panels", Gest. Prod., São Carlos, v. 24, n. 1, (2017) p. 5063,20

[15] Hair Jr, J. F., G. T. M. Hult, C. Ringle, and M. Sarstedt, "A primer on partial least squares structural equation modeling (PLS-SEM)", Sage Publications, 2016.

[16] Hair, J.F., W.C. Black, B.J. Babin, R.E., Anderson, and R. L. Tatham, "Multivariate data analysis", Vol 7: Prentice Hall, Upper Saddle River, NJ, 2010.

[17] Haußmann, C., Y. K. Dwivedi, K. Venkatachalam, and M. D. Williams, "A summary and review of Galbraith's organizational information processing theory", Information Systems Theory, Springer, New York, NY, 2012, pp71-93.

[18] Hawkins, T.G. and W.A. Muir, "An exploration of knowledge-based factors affecting procurement compliance", Journal of Public Procurement, 14(1), 2014, pp.1-32.

[19] Henseler J, C.M. Ringle, Sinkovics R.R. "The use of partial least squares path modeling in international marketing". In New challenges to international marketing 2009 Mar 6 (pp. 277-319). Emerald Group Publishing Limited.

[20] Henseler J, T.K. Dijkstra, Sarstedt M., Ringle C.M., Diamantopoulos A, Straub D.W., Ketchen Jr D.J., Hair J.F., Hult G.T., Calantone R.J. "Common beliefs and reality about PLS: Comments on Rönkkö and Evermann (2013)". Organizational research methods. 2014 Apr.17 (2):182-209.

[21] Ince H., S. Z. Imamoglua, and Turkcana, H., "The Effect of Technological Innovation Capabilities and Absorptive Capacity on Organization Innovativeness: A Conceptual Framework", 12th International Strategic Management Conference, ISMC 2016, 28-30 October 2016, Antalya, Turkey, 2016

[22] Kauppi, K., A. Brandon-Jones, S. Ronchi, and E.M. Van Raaij, "Tools without skills: Exploring the moderating effect of absorptive capacity on the relationship between epurchasing tools and category performance", International Journal of Operations and Production Management, 33(7), 2013.

[23] Lane, P. J., B. R. Koka, and S. Pathak, "The reification of absorptive capacity: A critical review and rejuvenation of the construct" Academy of management review, 31(4), 2006, 833-863.

[24] Limaj, E., and E.W. Bernroider, "A comparative analysis of social information and communication systems for supporting potential absorptive capacity", In Social Knowledge Management in Action - Springer, Cham, 2017, pp.61-79.

[25] MacKenzie, S. B., P. M. Podsakoff, and N. P. Podsakoff, "Construct measurement and validation procedures in MIS and behavioral research: Integrating new and existing techniques", MIS Quarterly, 35(2), 2011, 293-334.

[26] Marcolin, B.L., Compeau, D.R., Munro, M.C. and Huff, S.L. Assessing user competence: Conceptualization and measurement. Information systems research, 11(1), 2000, pp.37-60.

[27] McKevitt, D., Davis, P., Woldring, R., Smith, K., Flynn, A. and McEvoy, E., "An exploration of management competencies in public sector procurement", Journal of Public Procurement, (2012) 12(3), pp.333-355.

[28] $\mathrm{Mu}$ E, Kirsch LJ, Butler BS. The assimilation of enterprise information system: An interpretation systems perspective. Information \& Management. 2015 Apr 1; 52(3):359-70.

[29] Organisation for Economic Co-operation and Development, "OECD Principles for Integrity in Public Procurement" 2009. Available on https://www.oecd.org/gov/ethics/48994520

[30] Paim, R., H. Mansur Caulliraux, and R. Cardoso, "Process management tasks: a conceptual and practical view", Business process management journal, 14(5), 2008, pp.694-723.

[31] Rai, A., X. Tang, P. Brown, and M. Keil, "Assimilation patterns in the use of electronic procurement innovations: A cluster analysis. Information \& Management, 43(3), 2006, pp.336-349.

[32] Rai, A., X. Tank, and P. Brown, "Organization Assimilation of Electronic Procurement", Journal of Management Information Systems, 26(1), 2009, 257-296.

[33] Saraf N, Liang H, Xue Y, Hu Q. How does organizational absorptive capacity matter in the assimilation of enterprise information systems? Information systems journal. 2013 May; 23(3):245-67.

[34] Teo, H. H., W. Wan, X. Wang, and K. K. Wei, "Effects of Absorptive Capacity on Organization Predisposition Towards Information Systems", In Proceedings of the 24th International Conference on Information Systems, S. T. March, A. Massey, and J. I. DeGross (eds.), Seattle, WA, 2003, pp. 121-133.

[35] Todorova, G. and B., Durisin, "Absorptive capacity: Valuing a reconceptualization", Academy of management review, 32(3), 2007, 774-786.

[36] Tu, Q., Vonderembse, M., Ragu-Nathan, T. and Sharkey, T. "Absorptive capacity: Enhancing the assimilation of time-based manufacturing practices". Journal of Operations Management, Vol. 24 No. 5, 2006, pp. 692-710.

[37] Tushman, M. L., and D. A. Nadler, "Information processing as an integrating concept in organizational design", Academy of management review, 3(3), 1978, 613-624.

[38] Vaidya, K., A. S. M. Sajeev, and J., Gao, "EProcurement Assimilation: An Assessment of e-Business Capabilities and Supplier Readiness in the Australian 
Public Sector”, In ICEC '05 (pp.429-434).

[39] Vaidya, Kishor, and John Campbell. "Multidisciplinary approach to defining public eprocurement and evaluating its impact on procurement efficiency." Information Systems Frontiers 18, no. 2 (2016): 333-348.

[40] Volberda H., N. Foss, and M. Lyles, "Absorbing the Concept of Absorptive Capacity: How to Realize Its Potential in the Organization Field", Organization Science 21 (4), 2010, 931.

[41] Weele, A.J.V., "Purchasing and supply chain management: analysis, strategy, planning and practice", 5th edn, Cengage Learning, Andover. (2010)

[42] Wei, J., P. B. Lowry, and S. Seedorf, "The assimilation of RFID technology by Chinese companies: A technology diffusion perspective", Information \& Management, 52, 2015, pp628-642.

[43] Wu, F., G. Zsidisin, and A. Ross, “Antecedents and outcomes of e-procurement adoption: an integrative model", IEEE Transactions on Engineering Management, 54(3), 2007, pp.576-587.

[44] Yoon, C. Y. "The effect of factors of end-user task performance in a business environment: Focusing on computing competency". Computers in Human Behavior, 25(6), 2009, 1207-1212.

[45] Zahra, S. A., and G. George, "Absorptive capacity: A review, reconceptualization, and extension", Academy of management review, 27(2), 2002, 185-203. 